\title{
CD40 in coronary artery disease: a matter of macrophages?
}

\author{
Matthijs F. Jansen ${ }^{1,2} \cdot$ Maurits R. Hollander ${ }^{3}$ Niels van Royen $^{3} \cdot$ Anton J. Horrevoets $^{1}$ • \\ Esther Lutgens ${ }^{2,4}$
}

Received: 3 February 2016/Accepted: 5 April 2016/Published online: 4 May 2016

(c) The Author(s) 2016. This article is published with open access at Springerlink.com

\begin{abstract}
Coronary artery disease (CAD), also known as ischemic heart disease (IHD), is the leading cause of mortality in the western world, with developing countries showing a similar trend. With the increased understanding of the role of the immune system and inflammation in coronary artery disease, it was shown that macrophages play a major role in this disease. Costimulatory molecules are important regulators of inflammation, and especially, the CD40L-CD40 axis is of importance in the pathogenesis of cardiovascular disease. Although it was shown that CD40 can mediate macrophage function, its exact role in macrophage biology has not gained much attention in cardiovascular disease. Therefore, the goal of this review is to give an overview on the role of macrophage-specific CD40 in cardiovascular disease, with a focus on coronary artery disease. We will discuss the function of CD40 on the macrophage and its (proposed) role in the reduction of atherosclerosis, the reduction of neointima formation, and the stimulation of arteriogenesis.
\end{abstract}

Esther Lutgens

e.lutgens@amc.uva.nl

1 Department of Molecular Cell Biology and Immunology, VU University Medical Centre, Amsterdam, The Netherlands

2 Department of Medical Biochemistry, Academic Medical Centre, Meibergdreef 15, 1105AZ Amsterdam, The Netherlands

3 Department of Cardiology, VU University Medical Center, Amsterdam, The Netherlands

4 Institute for Cardiovascular Prevention (IPEK), Ludwig Maximilians University, Munich, Germany
Keywords CD40 - Macrophage - Atherosclerosis · Arteriogenesis · Neointima formation - Ischemic heart disease

\section{Introduction}

The TNF receptor superfamily member 5 (TNFRSF5), or $\mathrm{CD} 40$, is a costimulatory molecule that was originally discovered on B-cells and other antigen presenting cells (APCs) [110]. CD40 is activated by its ligand, CD40L(TNFSF5) [89]. CD40 is expressed on a multitude of immune cells and non-immune cells, with functions varying per cell type [21, 41]. In B-cells, CD40 ligation induces T-cell-dependent immunoglobulin class switching [42], memory B-cell development [48], and germinal center formation $[71,79]$. In dendritic cells, CD40 ligation induces more effective antigen presentation [17, 115, 124], enhances T-cell stimulatory capacity, and induces production of several inflammatory cytokines and chemokines [18]. It was discovered recently that T-cells also express CD40 but not much is known about its function. T-cell CD40 seems to mediate CD8+ T-cell memory [12], can contribute to T-cell activation [107], and is associated with autoimmune disease [142, 143]. On monocytes, CD40 stimulation induces the production of inflammatory cytokines and chemokines [75], and matrix metalloproteinases [38] and, similar to CD40 on dendritic cells, induces more potent antigen presentation [17, 115, 124]. The effects of CD40 on macrophages will be described in detail below.

In the 1990s, it was discovered that blocking CD40L limits atherosclerosis [91, 93, 128] and induces a stable plaque phenotype in mice [90]. Thereafter, it was shown that knocking out CD40, the receptor for CD40L, 
induced a similar phenotype [92]. Our laboratories have shown the importance of CD40 on hematopoietic cells, and macrophages in particular. We showed that a deficiency of hematopoietic CD40 decreased atherosclerosis and induced plaque stabilization in CD40 knock-out mice [92]. Macrophages of these mice were of the regulatory M2 phenotype. We also showed that the antiarteriogenic protein galectin-2 shifts proarteriogenic, CD40-negative macrophages into proinflammatory, and CD40-positive macrophages, resulting in compromised arteriogenesis [158]. We identified galectin-2 to be highly expressed in monocytes of human chronic total coronary occlusion (CTO) patients with a poor collateral network, compared with CTO patients with a well-developed collateral network [145]. These findings, in combination with the large overlap between functions of CD40 and macrophages in cardiovascular disease, suggest an important role of macrophagespecific CD40 in cardiovascular disease. Specific inhibition of macrophage CD40 might act as a "double-edged sword" by inhibiting atherosclerosis and stimulating arteriogenesis, resulting in a reduced ischemic burden without interfering in adaptive immunity.

\section{Macrophages in cardiovascular disease}

Monocytes and macrophages largely contribute to the pathophysiology of cardiovascular diseases, for example, in atherosclerosis [4, 37, 57, 62, 120, 164] and arteriogenesis $[55,58]$. Both monocytes and macrophages can, at the extremes, be divided in a proinflammatory phenotype and a healing phenotype. The interplay and balance between these two phenotypes have shown to be of importance in, for example, atherosclerosis [25, 29, 130] and myocardial infarction $[37,154]$. In murine monocytes, the proinflammatory phenotype is defined as Ly6C high, while the healing phenotype is defined as Ly6C low [159]. Ly6C high monocytosis is regarded as one of the first steps in the inflammatory response in atherosclerosis, as Ly6C high monocytes activate endothelium, infiltrate into the intima, and become lesional macrophages. Furthermore, in atherosclerosis models, such as the apolipoprotein (ApoE) deficient mouse, hypercholesterolemia is associated with Ly6C high monocytosis. Inhibition of the Ly6C high monocytosis abolishes atherosclerosis in hypercholesterolemic mice [26, 87, 136]. In humans proinflammatory, or classical, monocytes are generally defined as CD14++/ CD16-, while the healing, or non-classical, phenotype is defined as $\mathrm{CD} 14+/ \mathrm{CD} 16++$ [166]. An intermediate, CD14++/CD16+ population can also be observed in humans [99, 153]. In concurrence with the animal model described above, in humans, CD14++/CD16- monocytosis is associated with atherosclerosis and is an independent predictor of cardiovascular events [61, 123]. In macrophages, the phenotypic spectrum is defined by the proinflammatory M1 macrophages that are induced by T-helper 1 cytokines, and by M2 macrophages that are induced by Th- 2 cytokines. The M2 macrophages can be subclassified into wound healing (M2a), regulatory (M2b, M2c), and M2d subtypes [24, 25, 104]. In addition, atherosclerosis-associated macrophage phenotypes have been discovered, i.e., M(Hb), Mox, Mhem, and M4 macrophages [24, 25]. Consequently, a large number of macrophage phenotypic markers have evokes (reviewed by Mosser et al. [104]. and Colin et al. [25]). While CD40 is not mentioned in these reviews, it has proved to be a distinctive marker for M1 macrophages [148, 149]. In experimental atherosclerosis models, the M1 and the plaque specific M4 subtypes are proinflammatory and proatherogenic and seem to cause a vulnerable plaque phenotype. The M2 phenotype and the plaque specific $\mathrm{M}(\mathrm{hb})$ and Mhem are anti-inflammatory and antiatherogenic. The role of the Mox phenotype is currently not well understood [25, 29]. The role of the M2 subtypes has not been defined further yet. In arteriogenesis in animal models, the shift toward M2 phenotype (no data on subtypes) improves arteriogenesis and reduces ischemia [51, 138, 140]. In humans, M1 macrophages are associated with plaque instability, both in ischemic stroke and in myocardial infarction [23, 81, 134]. A word of caution should be added, regarding the dichotomous distinction between M1 and M2 macrophages, as these terms are increasingly discouraged by immunologists. In vivo, a wide range of M1and M2-like macrophages can be distinguished. While older studies use the M1/M2 nomenclature, it is now encouraged to use multiple markers to describe the macrophage phenotype [47]. However, this review will still use the M1/M2 nomenclature, as the studies described all use this nomenclature.

\section{CD40 in clinical disease}

Cardiovascular diseases share many traits of their pathophysiology with other autoimmune diseases, such as rheumatoid arthritis [68], systemic sclerosis [16], systemic lupus erythematosus [3], or inflammatory bowel disease [49, 72, 139]. CD40 and CD40L were shown to have a pivotal role in these diseases [27, 33, 96, 114]. Interestingly, higher sCD40L levels in patients with Crohn's disease even predicted thicker intima and media in their carotid arteries [72]. In cardiovascular diseases, blocking CD40 signaling has never been tested in clinical trials. Anta- and agonistic CD40 antibodies, however, have been tested in other chronic inflammatory diseases and cancer. Below is a brief overview of these trials and the 
effectiveness and side effects of blocking or activating CD40 signaling.

In 1999, the first clinical trials started using an antiCD40L antibody as a treatment for systemic lupus erythematosus, lupus glomerulonephritis, and immune thrombocytopenic purpura. The anti-CD40L antibody treatment showed an improvement in the number of platelets in immune thrombocytopenic purpura but did not improve performance scores in systemic lupus erythematosus [11, 28, 69, 78]. Blocking CD40L was effective in lupus glomerulonephritis, where it markedly reduced hematuria. However, this trial was ended prematurely because of the high incidence of thromboembolic events [11]. These thromboembolic events are most likely due to the fact that $\mathrm{CD} 40 \mathrm{~L}$ is also present on platelets, as inhibition of CD40L causes platelet aggregates to become unstable and to embolize [5]. Since the anti-CD40L antibody treatment was deemed unsafe, attention was shifted toward the CD40 molecule.

Dacetuzumab is a humanized anti-CD40 agonistic mAb, which triggers CD40-mediated signaling in various cell types [53]. It has been tested in several hematologic malignancies. In a phase I single agent study of patients with relapsed B-cell non-Hodgkin's lymphoma, six of 50 patients had objective response, and an additional thirteen had documented stable disease [2]. For relapsed chronic lymphocytic leukemia, a phase I single agent study was performed. In this study, none of the patients achieved an objective response; however, five out of twelve patients showed stable disease [43]. In refectory multiple myeloma, single agent therapy with dacetuzumab showed no objective response in a phase I study [60]. In refractory diffuse large B-cell lymphoma, a phase I study initially showed promising results of dacetuzumab as a single agent, with objective responses in four of 46 patients and 13 cases of stable disease [30]. However, a follow-up study showed no benefit of dacetuzumab on top of the existing last-resort chemotherapy [36]. In these studies, about two-thirds of patient's experienced adverse events classified as grade 1-2 out of 4 among them were fatigue, headache, pyrexia, chills, nausea, anemia, thrombocytopenia, and hypotension. Non-infectious eye disorders, including conjunctivitis and ocular hyperemia, were also seen. A few grade 3 adverse events were seen, including malignant neoplasm progression, severe anemia, pleural effusion, thrombocytopenia, and severe infections. Some grade 4 events were seen, including aseptic meningitis and hyperviscosity syndrome $[2,30,36,43,60]$.

Lucatumumab (or HCD122) is a fully humanized antagonistic antibody against CD40 and exerts its primary function through opsonization followed by antibody-dependent cell-mediated cytotoxicity (ADCC) [53]. It has been tested in a single-agent phase I study of relapsed chronic lymphocytic leukemia [15]. Here, one of 26 patients had a partial response and sixteen had a stable disease. For relapsed or refractory multiple myeloma, a single agent phase I study was performed in 28 patients. Twelve patients had a stable disease after treatment and one patient maintained a partial response for up to 8 months [8]. A phase I/IIa study was performed for advanced non-Hodgkin and Hodgkin lymphoma in 111 patients. In this study, the overall response rate by computed tomography among patients was $33 \%$ [35]. Overall, most adverse events observed in these studies were mild to moderate, including neutropenia, thrombocytopenia, fatigue, headache, chills, fever, and nausea, cytokine release syndrome symptoms (mostly grades $1-2$, sometimes grades 3-4), non-infectious ocular inflammation, and elevated hepatic enzymes. A few serious adverse events were seen, including dyspnea, pyrexia elevated liver enzymes and infections. One death due to severe sepsis was reported $[8$, $15,35]$.

An antagonistic anti-CD40 antibody, ch5D12, has been tested in 18 patients with mild to moderate Crohn's disease. Based on Crohn's Disease Activity Index (CDAI) scores, the overall response rate was $70 \%$, remission was achieved in $22 \%$ of patients, and ch5D12 was well tolerated. Described side effects were mild, including headache, muscle aches, or joint pains [70].

While the side effects are described as overall mild to modest in these papers, this is in comparison with the conventional therapy for cancer or Crohn's disease. However, in chronic use for ischemic heart diseases, the side effects would be more damaging than beneficial. Since blocking CD40 or CD40L systemically is not suitable for the treatment of ischemic heart diseases because of predicted severe side effects, such as immune suppression, targeting CD40(L) downstream targets and selected CD40 effector cells may be a preferred strategy.

\section{CD40 and macrophages}

The findings described above, in combination with the large overlap between functions of CD40 and macrophages in cardiovascular disease suggest an important role of macrophage-specific CD40 in cardiovascular disease. Unfortunately, there is not much data available on signaling pathways elicited by CD40 in macrophages or macrophage subtypes. Since CD40 is expressed mostly on M1 macrophages [148, 149], it can be assumed that CD40 signaling is predominantly active in M1 macrophages. Ligation of CD40 on macrophages induces a more potent antigen presentation, with the upregulation of MHC class II, costimulatory molecules CD80, CD86, and CD40 itself [135]. Furthermore, ligation of CD40 stimulates the 
production of proinflammatory cytokines and chemokines by macrophages, including TNF $\alpha$, IL-1 ( $\alpha$ and $\beta$ ), IL-6, IL8, IL-12, CCL 2, 3, 4, and 5 [135]. CD40 also induces several other molecules, such as matrix metalloproteinases, nitric oxide, and possibly iNOS (NOS2) and COX-2. In addition, ligation of CD40 on near-apoptotic cells rescues them from apoptosis [118, 135].

However, since these studies are all performed in vitro, caution is needed when interpreting these interactions as the response CD40 induces in macrophages seems highly dependent on the environment. In vitro, the presence of IL-4 or IL-10 has been shown to induce quite different results in downstream CD40 signaling in macrophages. IL-4 blocks CD40 mediated rescue from apoptosis, while IL-10 does not [117]. IL-10 significantly inhibited CD40-induced activation of the ERK, p38 MAPK, and NF- $\kappa$ B pathways, whereas IL-4 only affects the ERK pathway [66]. CD40-CD40L interaction induces ROS production, the synthesis of ICAM1, and activation of stress response proteins (p38 MAP kinase and HSP27) only in the presence of hypoxia, indicating that CD40(L) mediates the induction of oxidative stress in these cells [20]. When comparing a model of an atherosclerotic plaque in mice [90] to a model of lung fibrosis in mice [1], opposite reactions to the same stimuli are seen due to the influence of tissue environment on CD40 signaling. In both models, inhibition of CD40-CD40L signaling results in a downregulation of inflammation. However, in atherosclerosis, anti-CD40L antibody treatment resulted in the upregulation of TGF-beta on macrophages, whereas in irradiationinduced lung injury, it caused downregulation of TGF-beta.

Environmental differences like these are important in tumor progression $[111,113]$, but there is also indirect evidence that these environmental differences play a role in other diseases. For example, the lack of apoptosis of macrophages inside the atheromatous plaque is thought to aggravate atherosclerosis $[88,146]$. It was shown that IL-4 blocked CD40-mediated rescue from apoptosis, while IL10 does not [117]. Though never proven, one could imagine that the plaque environment alters CD40 signaling, and thus affects atherosclerosis.

\section{TNF-receptor-associated factors}

As CD40 does not have the ability to initiate its own intrinsic activity but requires adaptor molecules, it is important to note the functions of these molecules, with a focus on their functions in macrophages. The TNF-receptor-associated factor (TRAF)-family of proteins can bind to the cytoplasmic tail of CD40 and subsequently recruit kinases and other effector proteins [127]. All TRAF-family members, with the exception of TRAF5, are ubiquitously expressed, suggesting that they may perform significant physiological and cellular functions in multiple organs and cell types. The TRAF-family members can be recruited by a variety of receptors, among which CD40. CD40 can, after activation by $\mathrm{CD} 40 \mathrm{~L}$, recruit several different TRAFfamily members. Depending on the TRAF-molecule activated, different transduction cascades are induced. These transduction cascades activated by the different TRAFs can have opposite effects. Unfortunately, what regulates the recruitment of a certain TRAF-family member to CD40 remains unclear. Of the seven known TRAF-family members, CD40 can bind five (TRAFs 1, 2, 3, 5, and 6) [119, 155]. CD40 contains three binding sites, one for the TRAF 1, 2, and 3, one for TRAF6 [119] and a secondary TRAF2 binding site. There is some conflicting evidence whether or not TRAF 5 can bind directly to the binding site of TRAF 1,2 , and 3 [67] or that it indirectly binds to it via an heterodimeric complex with TRAF3 $[119,161]$. Below is a brief description of the different functions of the TRAF proteins when CD40 ligation occurs. A graphical overview of the main pathways involved in CD40-TRAF signaling is shown in Fig. 1. As TRAF4 and TRAF7 do not bind to CD40, they will not be discussed.

\section{TRAF1}

TRAF1, like all TRAFs, can be recruited to a variety of TNRF receptor members, including CD40, TNFR I/II, and RANK [64]. In general, it is thought that TRAF1 has a role as a negative regulator of signaling in TNF receptors. This is displayed in TRAF1 knock-out models, where T-cells respond in a hyper proliferative manner in response to stimulation [82, 162]. However, the possible role as negative regulator has not yet been researched in macrophages. On the CD40 protein, TRAF1 shares a binding site with TRAF 2 and 3 and binds only weakly to this site [119]. No functional data are known about CD40-TRAF1 signaling on macrophages. However, ligation of CD40 on T- and B-cells that were deficient in TRAF1 did not show any differences compared with normal T- and B-cells [82, 162]. However, in cell cultures of dendritic or HeLA cells, TRAF1 negatively regulates CD40-TRAF2 signaling [6, 40]. Of interest, this review is a study by Missiou et al., which showed that TRAF1 deficiency reduces atherosclerosis by limiting the adhesion of monocytes to the vessel wall, suggesting that TRAF1 plays a role in monocyte adhesion [97]. However, since TRAF1 interacts with more receptors that just CD40, it is not known if this inhibition of adhesion was solely due to the lack of CD40-TRAF1 signaling.

\section{TRAF2}

The general functions of TRAF2 are very broad. TRAF2 is required in $\mathrm{T}$ - and $\mathrm{B}$-cell signaling and inflammatory 
Fig. 1 Overview of the main pathways involved in CD40TRAF signaling. a TRAF 2/3/5 induces about $40 \%$ of TNF production; however, they do not influence (canonical) NF$\kappa \mathrm{B}$. Therefore, an alternative pathway must be present. Based on data from B-cells, this is most likely the non-canonical NF- $\kappa \mathrm{B}$ pathway. b TRAF 2/3/5 is required for the IKKcomplex; however, they do not

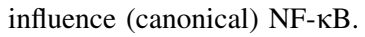
Therefore, an alternative pathway is likely present. c Much of the downstream targets of CD40-TRAF signaling still need to be uncovered. Of the majority of molecules produces by macrophages in response to CD40 signaling, no TRAF molecule or further pathway has been determined

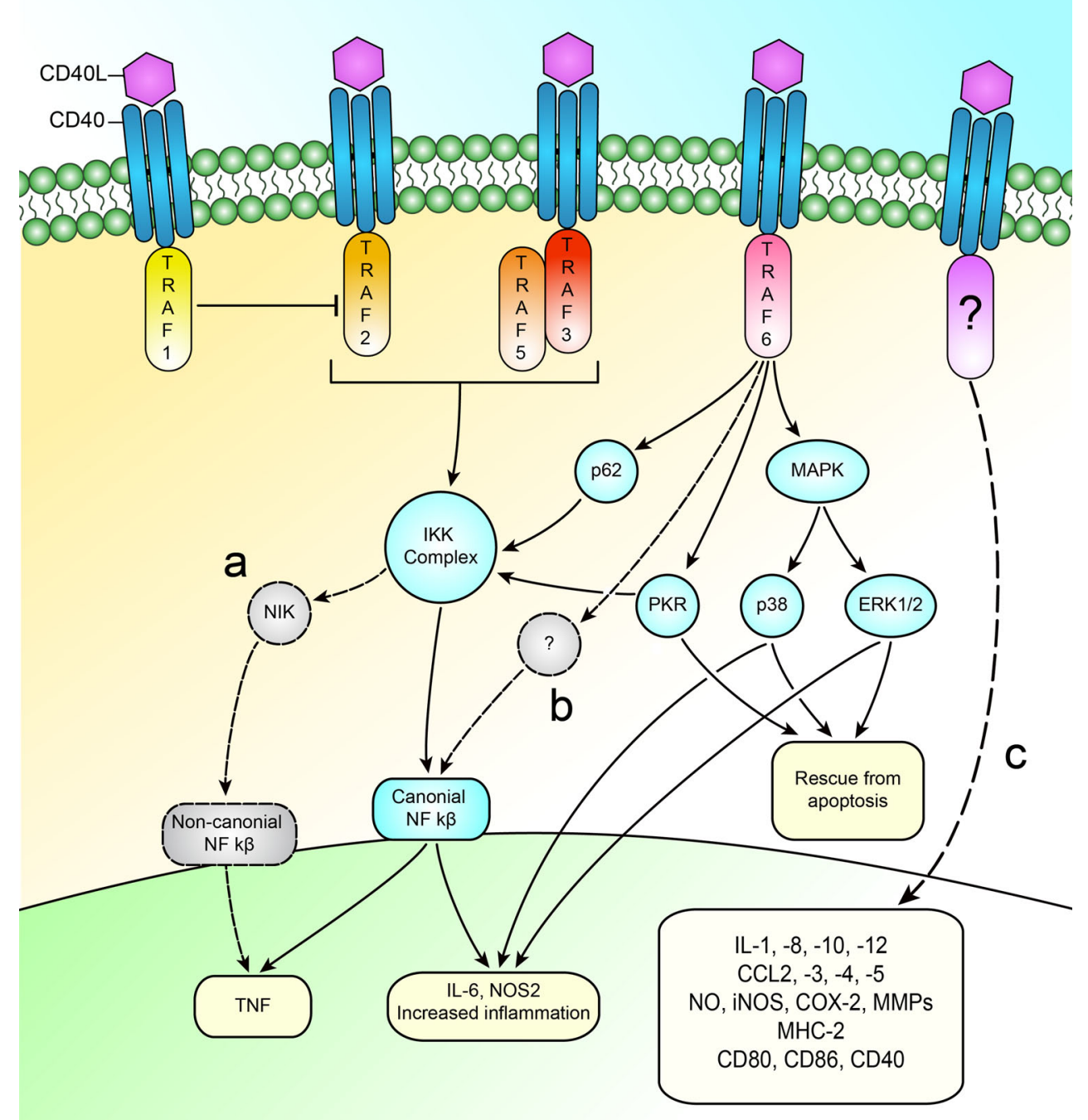

responses, but it is also required for organogenesis and cell survival [7]. TRAF2 activates the canonical NF- $\kappa \mathrm{B}$ signaling pathways [103] and also seems to be a negative regulator of the non-canonical NF- $\kappa B$ signaling pathways, as TRAF2 deficiency results in hyperreactivity of this pathway [7]. On the CD40 protein, TRAF2 shares its binding site with TRAF1 and 3. It binds strongly and directly to this binding site [119]. TRAF2 seems to require an intact lipid raft to function, as CD40-TRAF2 signaling on dendritic cells is largely absent when disturbing the lipid raft [147]. On the macrophage, some evidence points toward the requirement of TRAF2 expression and subsequent degradation after stimulation with CD40L for the differentiation of monocytes into fully functional macrophages [34], suggesting that TRAF2 has a low concentration in macrophages. A defective TRAF2, 3 , and 5 binding site on CD40 in macrophages does not completely impair the inflammatory response to $\mathrm{CD} 40 \mathrm{~L}$; however, it does result in a lower TNF production (ca. $40 \%$ of total production). Furthermore, CD40-TRAF2/3/5 deficiency leads to an inability to activate the IKK complex. However, this defect has no consequences for NF-kB activation, IL-6 production, or ERK1/2 activation [65, 106].

\section{TRAF3}

The function of TRAF3 has long been a mystery, as researching it proved difficult. TRAF3 knockout mice have a relatively normal gestation period; however, soon after birth, the mice die prematurely within two weeks of age with symptoms, including stunted growth and progressive hypoglycemia, hypercortisolemia, and leukopenia [54]. Relatively, recently, it was discovered that TRAF3 is a powerful negative regulator of the non-canonical NF- $\mathrm{KB}$ signaling pathways and a modulator of viral immunity [54]. On the CD40 molecule, as mentioned before, TRAF3 
shares its binding site with TRAF1 and 2. It binds strongly and directly to this binding site [119]. TRAF3, like TRAF2, also seems to require an intact lipid raft to function; however, the effect of disturbing the lipid raft is not as large as with TRAF2 [147]. On macrophages, TRAF3 is suggested to only be present in low concentrations. Monocytes showed a strongly immunoreactivity for TRAF3, but macrophages typically contained little or no TRAF3 immunoreactivity [77].

\section{TRAF5}

TRAF5 is highly similar to TRAF2, in both structure and function. However, whereas TRAF2 is expressed ubiquitously, TRAF5 expression is only found at significant levels in lung, thymus, spleen, and kidney and at lower levels in the brain and liver [7]. A sole TRAF5 deficiency has interesting consequences. TRAF5 deficiency accelerates atherogenesis in a mice model by promoting the rolling and adhesion of inflammatory cells and macrophage LDL uptake, which might contribute to foam cell formation [98], suggesting an anti-inflammatory, antiatherogenic function of TRAF5. It is under discussion whether TRAF5 directly [67] or indirectly binds to CD40 via hetero-oligomers with TRAF3 [119, 161].

\section{TRAF6}

Generation of TRAF6 deficient mice revealed that TRAF6 plays crucial roles in several important processes and that other TRAFs cannot compensate for loss of TRAF6. These functions are extremely broad, including osteoclastogenesis, lymph node organogenesis, thymic selection, and central tolerance. It is essential for IL-1 signaling and required for most TLR-receptor signaling [63, 151]. Furthermore, TRAF6 mediates antiviral responses triggered by cytosolic viral DNA and RNA in a way that differs from that associated with TLR signaling [76]. On the CD40 protein, TRAF6 has a separate binding site, to which it weakly binds [119]. Upon binding, TRAF6 is required for the maturation of dendritic cells, the affinity maturation of immunoglobulins, and optimal function of CD8 $+\mathrm{T}$-cell homeostasis and memory development [63, 151]. In monocytes and macrophages, TRAF6 is responsible for the most downstream actions of CD40. It is required for TNF production, IL6 production, NF- $\kappa \mathrm{B}$ activation (through p62 [129]), ERK activity, IKK activation, PKR phosphorylation [106], and upregulation of NOS2 (in cooperation with TNF) [118]. Defective CD40-TRAF6 signaling has some interesting results in monocytes and macrophages. This deficiency induces the polarization of macrophages toward an anti-inflammatory regulatory $\mathrm{M} 2$ signature, induces a reduced blood count of Ly6C high monocytes, and results in impaired recruitment of Ly6C high monocytes to the arterial wall. This defective signaling also results in a marked reduction of atherosclerosis in a mouse model [22, 92]. Recently, a small molecule CD40-TRAF6 inhibitor was developed. This compound showed significant survival benefits in sepsis and peritonitis in mice, with little side effects [163]. Furthermore, in a diet-induced obesity model, it was shown that the small molecule inhibitor reduced insulin resistance and, most important for this review, reduced the accumulation of immune cells to the adipose tissue and by skewing of the immune response toward a more anti-inflammatory profile [22, 144].

\section{Atherosclerosis}

In the pathophysiology of coronary artery disease, macrophage-specific CD40 plays a role in four major processes of the disease, atherosclerosis, neointima formation, angiogenesis, and arteriogenesis. Below the role of CD40 and macrophage-specific CD40 in these four processes will be described.

In atherosclerosis, atheromatous plaques develop due to the accumulation of apolipoprotein B containing lipoproteins in the inner lining of large- and medium-sized arteries [101]. When the coronary vasculature is affected, this can lead to ischemic heart disease. Ischemic heart disease is an important determinant of morbidity and mortality in developed countries, and is soon to attain this status worldwide [105]. As the atheromatous plaques develop, they grow larger and can restrict the vessel lumen resulting in symptoms, such as angina pectoris or claudicato intermittens, depending on the arterial bed affected. When atherosclerosis progresses, there is an increase in the incidence of the acute and most damaging complications, such as myocardial infarctions or ischemic cerebrovascular events. These acute complications of atherosclerosis are caused through either the rupture of a vulnerable plaque or the erosion of the endothelial layer [85, 108].

In the 1990s, it was discovered that inhibition of CD40 signaling by blocking CD40L limits the evolution of established atherosclerosis in mice [91, 93, 128]. In concurrence with these findings, it was shown that both early and delayed anti-CD40L antibody treatment induced a stable plaque phenotype [90]. Furthermore, it was shown that platelet CD40L mediates thrombotic and inflammatory processes in atherosclerosis [86]. Moreover, Leroyer et al. showed that microparticles isolated from human atherosclerotic lesions express CD40L, stimulate endothelial cell proliferation after CD4 ligation, and promote in vivo angiogenesis. The majority of these microparticles (93\%) were of macrophage origin, and therefore, microparticles released by macrophages could represent a 
major determinant of intraplaque neovascularization and, thus, plaque vulnerability [83]. In humans, CD40L predicts cardiovascular events. In unstable coronary artery disease, expression of $\mathrm{CD} 40 \mathrm{~L}$ on platelets and serum soluble CD40L levels are higher in patients compared with stable coronary disease or peripheral arterial disease [10, 45]. Furthermore, some studies show that sCD40L concentrations can predict clinical outcome in patients with acute coronary syndrome. However, other studies report no correlation between sCD40L levels and clinical outcome [112]. CD40L antibodies were tested clinically for other autoimmune diseases (see "CD40 in clinical disease"). However, trials were ended because of the high incidence of thromboembolic events [11]. These were most likely caused by to the fact that CD40L is also present on platelets, and inhibition of CD40L causes platelet aggregates to become unstable [5].

Thus, attention was shifted toward the CD40 protein. The involvement of CD40 signaling in atherosclerosis has been firmly established. In a mouse model that lacked both ApoE and CD40-TRAF6 signaling, atherosclerosis was abolished. Furthermore, the defective CD40 signaling induced a clinically favorable plaque phenotype, containing a high amount of fibrosis and a few inflammatory cells [92]. Furthermore, it was also shown that macrophage foam cell formation is highly dependent on CD40 in a study by Yuan et al. Soluble sCD40L significantly increased lipid deposition and foam cell formation. Disruption of the ligation between CD40 and CD40L either by small interfering RNA or by a blocking anti-CD40 antibody inhibited foam cell formation in response to sCD40L [160].Moreover, a meta-analysis of the rs1883832 CD40 SNP has shown a correlation between the $\mathrm{C}$ allele of this SNP and acute coronary syndrome in a Chinese population [157].

There is convincing evidence, suggesting a large role of CD40 on macrophages in atherosclerosis. The mouse knock-out model described above that lacked both ApoE and CD40-TRAF6 signaling displayed a reduced blood count of Ly6C high monocytes, an impaired recruitment of Ly6C high monocytes to the arterial wall, and polarization of macrophages toward an anti-inflammatory regulatory M2 signature. The reduction in atherosclerosis and the macrophage phenotype shift, both induced by defective CD40-TRAF6 signaling, is suggestive for a large role of CD40 on macrophages in atherosclerosis. In patients, CD40 on monocytes and macrophages is a marker for atherosclerosis, as shown by Bruemmer et al., who discovered that there is a direct association of CD40 expression on macrophages and smooth muscle cells and intimal thickness, suggesting a role in early plaque development [13]. In addition, CD40 on macrophages is associated with critical limb ischemia [14] and coronary artery calcification [137] in patients. Furthermore, patients with moderate hypercholesterolemia showed a significant increase in CD40 on monocytes (together with CD154 and P-selectin on platelets) compared with healthy subjects. A short-term therapy with an HMG-CoA reductase inhibitor significantly downregulated CD40 on monocytes [46, 150]. Unfortunately, a model detailing the effect on atherosclerosis by a specific deletion of CD40 on macrophages has not been published yet. On a side note, the difference described between males and females in the prevalence in cardiovascular diseases [141] might be in part due to a difference in CD40 on human macrophages. Androgens increase the expression of CD40 (among other atherosclerosis related genes) in male but not female macrophages, with functional consequences [109].

\section{Neointima formation}

Essentially, all damage to the vascular wall results in an increase in intimal thickness, or neointima formation. This process is associated with luminal narrowing, causing major complications in humans after arterial intervention (e.g., balloon angioplasty and stenting). In neointima formation, vascular smooth muscle cells proliferate within the intima. This process has been the main target for treatment in the form of drug eluting stents. However, the immunological process driving smooth muscle cell proliferation has not been fully uncovered, though initial cytokine release from platelets and macrophages, and further aggravation through macrophage produced cytokines has been suggested $[19,74]$. A role for CD8 + T-cells has also been shown, where the absence of CD8+ cells increases neointima formation. Conversely, the absence of CD4+ T-cells reduces neointima formation [31, 165].

In ApoE deficient mice in which denudation injury to the carotid arteries was induced, it was shown that blocking CD40L significantly reduced the exaggerated neointima formation, with a $>50 \%$ reduction in neointimal size and a $56 \%$ reduction in neointimal macrophage content [84]. Moreover, it was shown that blocking CD40L-CD40 signaling but not CD40L-Mac-1 reduces neointima formation [152]. In other studies, it was shown that neointima formation after both carotid artery ligation and femoral artery denudation injury was reduced in CD40-deficient mice compared with wild-type mice. Furthermore, a significant decrease in the recruitment of neutrophils (at 3 and 7 days) and macrophages (at 7 and 21 days) into injured artery was shown [59, 132]. Some contradictory data exist as Remskar et al. showed that after carotid artery injury in CD40L knockout mice, the intimal thickening was increased 3-fold compared with the thickening in wild-type mice [122]. Furthermore, it was shown by Donners et al. that inhibition of CD40L signaling did not reduce neointima formation in 
mice. CD40-knock-out mice, however, did have reduced neointima formation in the same study, suggesting that CD40, but perhaps not CD40L, plays a large role in neointima formation [32].

Like in atherosclerosis, TRAF6 seems to be the key regulator of CD40 signaling in neointima formation and arterial remodeling. Donners et al. showed that in mice deficient for CD40-TRAF6 signaling, neointima volume was reduced by $83 \%$. Also like atherosclerosis, they showed an impaired recruitment of macrophages to the vessel wall [32]. Another study demonstrated that in rabbits where carotid artery damage was induced by balloon inflation, CD40-TRAF6 signaling deficiency inhibited intimal cell replication, macrophage infiltration, and proteoglycan accumulation [100]. The role of CD40-TRAF6 signaling on vascular wall cells was also shown to be of importance, cooperating with kinase TAK1 [131, 133]. These data suggest a possible strategy for preventing neointima formation and, thus, improve outcome after vascular intervention by interfering in the CD40, most likely CD40-TRAF6, signaling of macrophages. However, no indication of its effectiveness compared with drug eluting stents, the current clinical practice, has been made.

\section{Angiogenesis}

Angiogenesis, a process seen in both health and disease, refers to the formation of new capillaries. The process of angiogenesis starts when several proangiogenic factors, such as vascular endothelial growth factor (VEGF) or basic fibroblast growth factor (bFGF), are excreted as a reaction to ischemia. These factors act by activating endothelial cells, causing them to proliferate and migrate into the perivascular space and eventually resulting in the formation of a new capillary lumen.

While angiogenesis is required for wound healing, increased angiogenesis is also associated with increased tumor growth and tumor metastasis [39, 80, 116]. This duality can also be in cardiovascular disease. Here, angiogenesis relieves ischemia by sprouting new capillaries [156] but also aggravates atherosclerosis by increasing plaque vascularization [102]. The functions of bFGF and VEGF are well known and often studied; however, other molecules, like CD40, seem to play crucial roles as well.

As described above, VEGF is a potent initiator of angiogenesis. Several studies have described a regulatory role for monocyte or macrophage CD40 in VEGF production. A study by Melter et al. shows that the treatment of HUVECs and monocytes with soluble CD40 ligand (sCD40L) results in an induction of VEGF and VEGFmRNA. In an in vitro endothelial cell growth assay, CD40L induced marked growth of HUVECs. Neutralizing
anti-VEGF antibody completely inhibited the effect of sCD40L on HUVEC growth. The study also showed a model of SCID mice bearing human skin transplants. sCD40L was injected into the human skin grafts and a marked induction in VEGF expression was found after 7 days in all sCD40L-treated skins compared with controls [95]. A similar study, performed for 6 weeks, showed similar results. In a model of SCID mice bearing human skin transplants, it was found that the injection of CD40Lexpressing cells, but not control cells, resulted in the in vivo expression of several angiogenesis factors (including VEGF and fibroblast growth factor) and a marked angiogenesis reaction [121]. Yet, another study showed that MCP-1 and CD40L stimulation of macrophages had a synergistic effect on COX-2 expression and subsequent VEGF production in gastric cancer [44]. All these studies clearly suggest that CD40 ligation is a potent stimulator angiogenesis and that the proangiogenic effect of CD40 is VEGF dependent.

While not many studies describing angiogenesis and CD40 on macrophages have been done, from the few that have been done a clear picture emerges, macrophage CD40 ligation induces and controls VEGF and other angiogenic factors, and seems to be an important factor in angiogenesis.

\section{Arteriogenesis}

Arteriogenesis refers to the widening of existing collateral arteries, as to increase blood flow.

These existing collateral arteries are present at birth and can be considered as alternative ways blood can flow from one point to another. Thus, when a vessel becomes partially obstructed, collateral vessels are somewhat able to compensate for the loss of blood flow. Arteriogenesis causes these collateral vessels to widen as to increase to blood flow to its original state.

The exact mechanisms of arteriogenesis have not yet been unraveled. Arteriogenesis is initiated by an increase in shear stress, caused by an increased blood flow in the collateral artery after partial obstruction of the main artery. The shear stress causes endothelial cells to become activated, and expresses several chemo-attractants and adhesion molecules [56]. These cause monocytes to adhere, migrate, and change into macrophages. These macrophages start to produce several cytokines and growth factors, which cause smooth muscle cells (SMCs) to proliferate, facilitating vascular luminal expansion and, thereby, an increased collateral perfusion.

It has been shown that having increased arteriogenesis, and thus, a better collateral network is highly beneficial. Patients with a better collateral network have smaller 


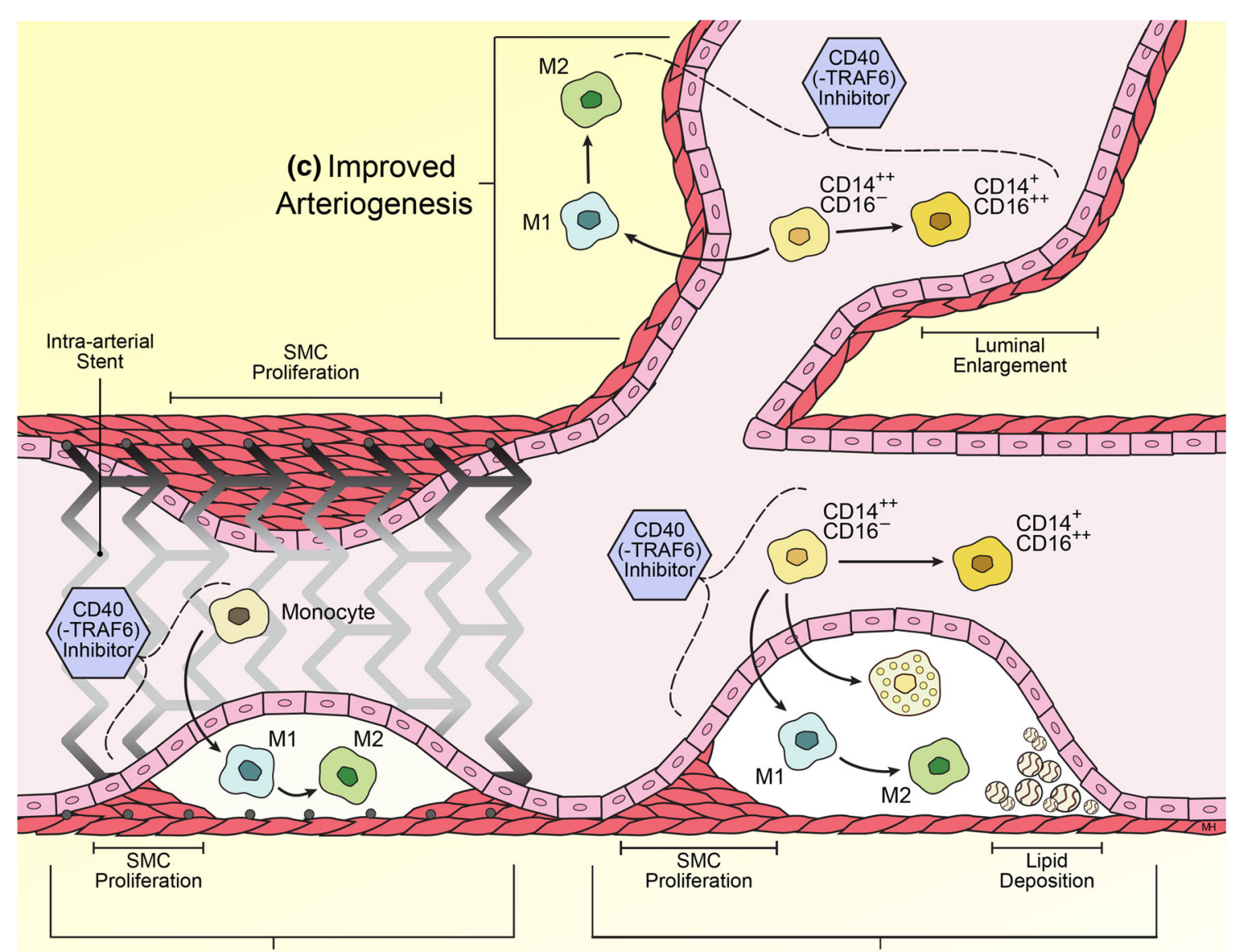

(a) Reduced Neointima Formation

(b) Reduced Atherosclerosis

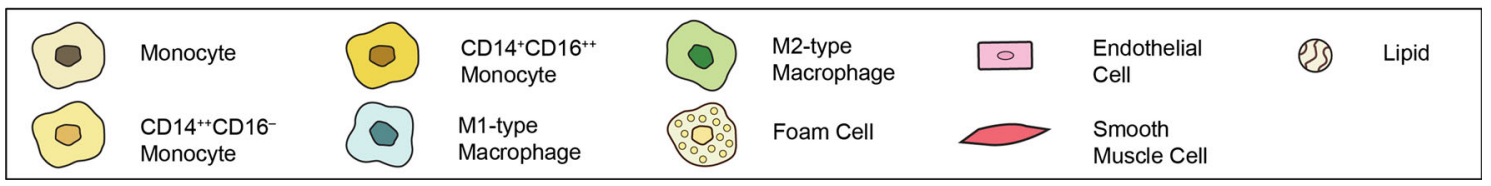

Fig. 2 Overview of the proposed mechanisms of CD40 (-TRAF6) inhibition on ischemic heart diseases. a In neointima formation, CD40(-TRAF6) inhibition reduces monocyte/macrophage recruitment into the vessel wall and shifts the macrophage subset balance toward the regulatory M2 phenotype. CD40(-TRAF6) inhibition markedly reduces neointima formation. b In atherosclerosis, CD40(TRAF6) inhibition induces Ly6C low monocytosis in mice (the human counterpart to Ly6C low is CD14+/CD16++). Furthermore,

lesions after myocardial infarction, less ventricular aneurisms, a relatively better left ventricular ejection fraction [50], less future cardiovascular events [9], and an improved survival [52, 94].

High expression of several immune modulating proinflammatory agents, such as Interferon-beta and Galectin-2, were shown to correlate with poor collateralization in humans and to directly inhibit this process in murine models $[126,145,158]$. It has been shown that the balance between M1 and M2 macrophages is of importance in it reduces monocyte/macrophage recruitment into the plaque, shifts the macrophage subset balance toward the regulatory M2 phenotype and reduces the formation of foam cells. CD40(-TRAF6) inhibition abolishes atherosclerosis. c In arteriogenesis, CD40(-TRAF6) inhibition induces Ly6C low monocytosis in mice (the human counterpart to Ly6C low is CD14+/CD16++). Moreover, shifts the macrophage subset balance toward the regulatory M2 phenotype. Both these changes have been shown to be highly beneficial in arteriogenesis

arteriogenesis. For example, in a mouse model by Takeda et al., skewing macrophages toward the M2-phenotype resulted in an increase in arteriogenesis and a marked decrease in ischemia as a result $[23,81,134]$. Although no direct studies on CD40 and arteriogenesis have been done, it has been convincingly shown that CD40 on macrophages might be involved. In a mouse model to test the effects of galectins on arteriogenesis, they show that galectin administration leads to increased numbers of CD40-positive M1 macrophages and reduced numbers of M2 
macrophages surrounding actively remodeling collateral arteries [158]. Suggesting that, in concurrence with the data described above, the shift toward CD40 positive M1 macrophages slows down arteriogenesis. As described above in the data presented about atherosclerosis, interfering with CD40 macrophage signaling induces a phenotype shift from M1 to M2 macrophages. While not many evidence exist yet, this might yield interesting new therapies for ischemic diseases.

\section{Discussion}

Macrophages are one of the most versatile cells, and the CD40 receptor on these cells has an equally large range of functions. As described above, there is substantial evidence for a large role of CD40 on macrophages in ischemic heart disease. Evidence is presented that the activation of CD40 on macrophages accelerates atherosclerosis, accelerates neointima formation, and attenuates arteriogenesis. The downstream target of CD40, TRAF6, plays a major role in these processes. An overview of the proposed mechanisms of CD40 inhibition on ischemic heart diseases is shown in Fig. 2.

While much research still needs to be done, the data presented in this review suggest that interfering in CD40 signaling on the macrophage is an excellent candidate for future cardiovascular therapies. Targeting CD40 specifically on the macrophage can be done in several ways. Macrophage-specific CD40 can be inhibited using a bispecific antibody that binds to both $\mathrm{CD} 40$ and a macrophage specific receptor. However, a more practical way is to use liposomes or HDL nanoparticles containing a CD40(TRAF6) inhibitor. These particles naturally target phagocytic cells, particularly macrophages, and thus specifically deliver the drugs to these cells $[73,125]$. Theoretically, a patient's ischemic burden could be drastically lowered by reducing or inhibiting CD40 signaling on macrophages. It could act as a "double-edged sword" by reducing the cause of ischemic heart disease (atherosclerosis) and promoting the cure (arteriogenesis). Equally important is the notion that reducing or inhibiting CD40 signaling on macrophages would not induce new problems, such as heightened tumor growth (induced by increased angiogenesis) or immunesuppression (by not interfering in the adaptive immune system). Although significant research is still required, CD40 on macrophages is an exciting and potent therapeutic target. A drug targeting this interaction could possibly lead to new therapies and improved care in cardiovascular disease.

Acknowledgments We acknowledge the support from the AAA (alliance grant AMC/VUMC), the Netherlands CardioVascular
Research Initiative (CVON2011-19) and the Deutsche Forschungsgemeinschaft (DFG) (SFB1123-A5 to E.L.), and the European Research Council (ERC-consolidator grant to EL).

\section{Compliance with ethical standards}

Ethical standards This manuscript does not contain clinical studies or patient data.

Conflict of interest The authors declare that they have no conflict of interest.

Open Access This article is distributed under the terms of the Creative Commons Attribution 4.0 International License (http://crea tivecommons.org/licenses/by/4.0/), which permits unrestricted use, distribution, and reproduction in any medium, provided you give appropriate credit to the original author(s) and the source, provide a link to the Creative Commons license, and indicate if changes were made.

\section{References}

1. Adawi A, Zhang Y, Baggs R, Rubin P, Williams J, Finkelstein J, Phipps RP (1998) Blockade of CD40-CD40 ligand interactions protects against radiation-induced pulmonary inflammation and fibrosis. Clin Immunol Immunopathol 89:222-230. doi:10.1006/ clin.1998.4606

2. Advani R, Forero-Torres A, Furman RR, Rosenblatt JD, Younes A, Ren H, Harrop K, Whiting N, Drachman JG (2009) Phase I study of the humanized anti-CD40 monoclonal antibody dacetuzumab in refractory or recurrent non-Hodgkin's lymphoma. J Clin Oncol 27:4371-4377. doi:10.1200/JCO.2008.21.3017

3. Al Gadban MM, Alwan MM, Smith KJ, Hammad SM (2015) Accelerated vascular disease in systemic lupus erythematosus: role of macrophage. Clin Immunol 157:133-144. doi:10.1016/j. clim.2015.01.008

4. Albiero M, Rattazzi M, Menegazzo L, Boscaro E, Cappellari R, Pagnin E, Bertacco E, Poncina N, Dyar K, Ciciliot S, Iwabuchi K, Millioni R, Arrigoni G, Kraenkel N, Landmesser U, Agostini C, Avogaro A, Fadini GP (2013) Myeloid calcifying cells promote atherosclerotic calcification via paracrine activity and allograft inflammatory factor-1 overexpression. Basic Res Cardiol 108:368. doi:10.1007/s00395-013-0368-7

5. Andre P, Prasad KS, Denis CV, He M, Papalia JM, Hynes RO, Phillips DR, Wagner DD (2002) CD40L stabilizes arterial thrombi by a beta3 integrin-dependent mechanism. Nat Med 8:247-252. doi:10.1038/nm0302-247

6. Arron JR, Pewzner-Jung Y, Walsh MC, Kobayashi T, Choi Y (2002) Regulation of the subcellular localization of tumor necrosis factor receptor-associated factor (TRAF) 2 by TRAF1 reveals mechanisms of TRAF2 signaling. J Exp Med 196:923-934. doi:10.1084/jem.20020774

7. Au P-YB, Yeh W-C (2007) Physiological roles and mechanisms of signaling by TRAF2 and TRAF5. In: Wu H (ed) TNF receptor associated factors (TRAFs). Springer, New York, pp 32-47

8. Bensinger W, Maziarz RT, Jagannath S, Spencer A, Durrant S, Becker PS, Ewald B, Bilic S, Rediske J, Baeck J, Stadtmauer EA (2012) A phase 1 study of lucatumumab, a fully human antiCD40 antagonist monoclonal antibody administered intravenously to patients with relapsed or refractory multiple myeloma. Br J Haematol 159:58-66. doi:10.1111/j.1365-2141.2012. 09251. $\mathrm{x}$

9. Billinger M, Kloos P, Eberli FR, Windecker S, Meier B, Seiler C (2002) Physiologically assessed coronary collateral flow and 
adverse cardiac ischemic events: a follow-up study in 403 patients with coronary artery disease. J Am Coll Cardiol 40:1545-1550. doi:10.1016/S0735-1097(02)02378-1

10. Blann AD, Tan KT, Tayebjee MH, Davagnanam I, Moss M, Lip GY (2005) Soluble CD40L in peripheral artery disease. Relationship with disease severity, platelet markers and the effects of angioplasty. Thromb Haemost 93:578-583. doi:10.1267/ THRO05030578

11. Boumpas DT, Furie R, Manzi S, Illei GG, Wallace DJ, Balow JE, Vaishnaw A, Group BGLNT (2003) A short course of BG9588 (anti-CD40 ligand antibody) improves serologic activity and decreases hematuria in patients with proliferative lupus glomerulonephritis. Arthritis Rheum 48:719-727. doi:10. 1002/art. 10856

12. Bourgeois C, Rocha B, Tanchot C (2002) A role for CD40 expression on CD8+ $\mathrm{T}$ cells in the generation of CD8+ T cell memory. Science 297:2060-2063. doi:10.1126/science.1072615

13. Bruemmer D, Riggers U, Holzmeister J, Grill M, Lippek F, Settmacher U, Regitz-Zagrosek V, Fleck E, Graf K (2001) Expression of CD40 in vascular smooth muscle cells and macrophages is associated with early development of human atherosclerotic lesions. Am J Cardiol 87:21-27. doi:10.1016/ S0002-9149(00)01266-2

14. Burdess A, Nimmo AF, Campbell N, Harding SA, Garden OJ, Dawson AR, Newby DE (2010) Perioperative platelet and monocyte activation in patients with critical limb ischemia. J Vasc Surg 52:697-703. doi:10.1016/j.jvs.2010.04.024

15. Byrd JC, Kipps TJ, Flinn IW, Cooper M, Odenike O, Bendiske J, Rediske J, Bilic S, Dey J, Baeck J, O’Brien S (2012) Phase I study of the anti-CD40 humanized monoclonal antibody lucatumumab (HCD122) in relapsed chronic lymphocytic leukemia. Leuk Lymphoma 53:2136-2142. doi:10.3109/10428194.2012. 681655

16. Cannarile F, Valentini V, Mirabelli G, Alunno A, Terenzi R, Luccioli F, Gerli R, Bartoloni E (2015) Cardiovascular disease in systemic sclerosis. Ann Transl Med 3:8. doi:10.3978/j.issn. 2305-5839.2014.12.12

17. Caux C, Massacrier C, Vanbervliet B, Dubois B, Vankooten C, Durand I, Banchereau J (1994) Activation of human dendritic cells through CD40 cross-linking. J Exp Med 180:1263-1272. doi:10.1084/jem.180.4.1263

18. Cella M, Scheidegger D, Palmer-Lehmann K, Lane P, Lanzavecchi A, Alber G (1996) Ligation of CD40 on dendritic cells triggers production of high levels of interleukin- 12 and enhances T cell stimulatory capacity: T-T help via APC activation. J Exp Med 184:747-752. doi:10.1084/jem.184.2.747

19. Chaabane C, Otsuka F, Virmani R, Bochaton-Piallat ML (2013) Biological responses in stented arteries. Cardiovasc Res 99:353-363. doi:10.1093/cvr/cvt115

20. Chakrabarti S, Rizvi M, Pathak D, Kirber MT, Freedman JE (2009) Hypoxia influences CD40-CD40L mediated inflammation in endothelial and monocytic cells. Immunol Lett 122:170-184. doi:10.1016/j.imlet.2008.12.010

21. Chatzigeorgiou A, Lyberi M, Chatzilymperis G, Nezos A, Kamper E (2009) CD40/CD40L signaling and its implication in health and disease. BioFactors 35:474-483. doi:10.1002/biof.62

22. Chatzigeorgiou A, Seijkens T, Zarzycka B, Engel D, Poggi M, van den Berg S, van den Berg S, Soehnlein O, Winkels $H$, Beckers L, Lievens D, Driessen A, Kusters P, Biessen E, GarciaMartin R, Klotzsche-von Ameln A, Gijbels M, Noelle R, Boon L, Hackeng T, Schulte KM, Xu A, Vriend G, Nabuurs S, Chung KJ, Willems van Dijk K, Rensen PC, Gerdes N, de Winther M, Block NL, Schally AV, Weber C, Bornstein SR, Nicolaes G, Chavakis T, Lutgens E (2014) Blocking CD40-TRAF6 signaling is a therapeutic target in obesity-associated insulin resistance.
Proc Natl Acad Sci USA 111:2686-2691. doi:10.1073/pnas. 1400419111

23. Cho KY, Miyoshi H, Kuroda S, Yasuda H, Kamiyama K, Nakagawara J, Takigami M, Kondo T, Atsumi T (2013) The phenotype of infiltrating macrophages influences arteriosclerotic plaque vulnerability in the carotid artery. J Stroke Cerebrovasc Dis 22:910-918. doi:10.1016/j.jstrokecerebrovasdis.2012.11.020

24. Cochain C, Zernecke A (2015) Macrophages and immune cells in atherosclerosis: recent advances and novel concepts. Basic Res Cardiol 110:34. doi:10.1007/s00395-015-0491-8

25. Colin S, Chinetti-Gbaguidi G, Staels B (2014) Macrophage phenotypes in atherosclerosis. Immunol Rev 262:153-166. doi:10.1111/imr.12218

26. Combadiere C, Potteaux S, Rodero M, Simon T, Pezard A, Esposito B, Merval R, Proudfoot A, Tedgui A, Mallat Z (2008) Combined inhibition of CCL2, CX3CR1, and CCR5 abrogates Ly6C(hi) and Ly6C(lo) monocytosis and almost abolishes atherosclerosis in hypercholesterolemic mice. Circulation 117:1649-1657. doi:10.1161/CIRCULATIONAHA.107.745091

27. Criswell LA (2010) Gene discovery in rheumatoid arthritis highlights the CD40/NF-kappaB signaling pathway in disease pathogenesis. Immunol Rev 233:55-61. doi:10.1111/j.01052896.2009.00862.x

28. Davis JC Jr, Totoritis MC, Rosenberg J, Sklenar TA, Wofsy D (2001) Phase I clinical trial of a monoclonal antibody against CD40-ligand (IDEC-131) in patients with systemic lupus erythematosus. J Rheumatol 28:95-101

29. De Paoli F, Staels B, Chinetti-Gbaguidi G (2014) Macrophage phenotypes and their modulation in atherosclerosis. Circulation 78:1775-1781. doi:10.1253/circj.CJ-14-0621

30. de Vos S, Forero-Torres A, Ansell SM, Kahl B, Cheson BD, Bartlett NL, Furman RR, Winter JN, Kaplan H, Timmerman J, Whiting NC, Drachman JG, Advani R (2014) A phase II study of dacetuzumab (SGN-40) in patients with relapsed diffuse large B-cell lymphoma (DLBCL) and correlative analyses of patient-specific factors. J Hematol Oncol 7:44. doi:10.1186/1756-8722-7-44

31. Dimayuga PC, Chyu KY, Lio WM, Zhao X, Yano J, Zhou J, Honjo T, Shah PK, Cercek B (2013) Reduced neointima formation after arterial injury in $\mathrm{CD} 4-/-$ mice is mediated by CD8+ CD28hi T cells. J Am Heart Assoc 2:e000155. doi:10. 1161/JAHA.113.000155

32. Donners MM, Beckers L, Lievens D, Munnix I, Heemskerk J, Janssen BJ, Wijnands E, Cleutjens J, Zernecke A, Weber C, Ahonen CL, Benbow U, Newby AC, Noelle RJ, Daemen MJ, Lutgens E (2008) The CD40-TRAF6 axis is the key regulator of the CD40/CD40L system in neointima formation and arterial remodeling. Blood 111:4596-4604. doi:10.1182/blood-2007-05088906

33. Doran JP, Veale DJ (2008) Biomarkers in systemic sclerosis. Rheumatology 47(Suppl 5):v36-v38. doi:10.1093/rheumatol ogy/ken 270

34. Dupoux A, Cartier J, Cathelin S, Filomenko R, Solary E, Dubrez-Daloz L (2009) cIAP1-dependent TRAF2 degradation regulates the differentiation of monocytes into macrophages and their response to CD40 ligand. Blood 113:175-185. doi:10. 1182/blood-2008-02-137919

35. Fanale M, Assouline S, Kuruvilla J, Solal-Celigny P, Heo DS, Verhoef G, Corradini P, Abramson JS, Offner F, Engert A, Dyer MJ, Carreon D, Ewald B, Baeck J, Younes A, Freedman AS (2014) Phase IA/II, multicentre, open-label study of the CD40 antagonistic monoclonal antibody lucatumumab in adult patients with advanced non-Hodgkin or Hodgkin lymphoma. Br J Haematol 164:258-265. doi:10.1111/bjh.12630

36. Fayad L, Ansell SM, Advani R, Coiffier B, Stuart R, Bartlett $\mathrm{NL}$, Forero-Torres A, Kuliczkowski K, Belada D, $\mathrm{Ng} \mathrm{E}$, 
Drachman JG (2015) Dacetuzumab plus rituximab, ifosfamide, carboplatin and etoposide as salvage therapy for patients with diffuse large B-cell lymphoma relapsing after rituximab, cyclophosphamide, doxorubicin, vincristine and prednisolone: a randomized, double-blind, placebo-controlled phase $2 \mathrm{~b}$ trial. Leuk Lymphoma 56:2569-2578. doi:10.3109/10428194.2015. 1007504

37. Fernandez-Velasco M, Gonzalez-Ramos S, Bosca L (2014) Involvement of monocytes/macrophages as key factors in the development and progression of cardiovascular diseases. Biochem J 458:187-193. doi:10.1042/BJ20131501

38. Ferrari-Lacraz S, Nicod LP, Chicheportiche R, Welgus HG, Dayer JM (2001) Human lung tissue macrophages, but not alveolar macrophages, express matrix metalloproteinases after direct contact with activated T lymphocytes. Am J Respir Cell Mol Biol 24:442-451. doi:10.1165/ajrcmb.24.4.4008

39. Folkman J (1995) Angiogenesis in cancer, vascular, rheumatoid and other disease. Nat Med 1:27-31. doi:10.1038/nm0195-27

40. Fotin-Mleczek M, Henkler F, Hausser A, Glauner H, Samel D, Graness A, Scheurich P, Mauri D, Wajant H (2004) Tumor necrosis factor receptor-associated factor (TRAF) 1 regulates CD40-induced TRAF2-mediated NF-kappaB activation. J Biol Chem 279:677-685. doi:10.1074/jbc.M310969200

41. Foy TM, Aruffo A, Bajorath J, Buhlmann JE, Noelle RJ (1996) Immune regulation by CD40 and its ligand GP39. Annu Rev Immunol 14:591-617. doi:10.1146/annurev.immunol.14.1.591

42. Fuleihan R, Ramesh N, Geha RS (1993) Role of CD40-CD40ligand interaction in Ig-isotype switching. Curr Opin Immunol 5:963-967. doi:10.1016/0952-7915(93)90113-7

43. Furman RR, Forero-Torres A, Shustov A, Drachman JG (2010) A phase I study of dacetuzumab (SGN-40, a humanized antiCD40 monoclonal antibody) in patients with chronic lymphocytic leukemia. Leuk Lymphoma 51:228-235. doi:10.3109/ 10428190903440946

44. Futagami S, Tatsuguchi A, Hiratsuka T, Shindo T, Horie A, Hamamoto T, Ueki N, Kusunoki M, Miyake K, Gudis K, Tsukui T, Sakamoto C (2008) Monocyte chemoattractant protein 1 and CD40 ligation have a synergistic effect on vascular endothelial growth factor production through cyclooxygenase 2 upregulation in gastric cancer. J Gastroenterol 43:216-224. doi:10.1007/ s00535-007-2151-8

45. Garlichs CD, Eskafi S, Raaz D, Schmidt A, Ludwig J, Herrmann M, Klinghammer L, Daniel WG, Schmeisser A (2001) Patients with acute coronary syndromes express enhanced CD40 ligand/ CD154 on platelets. Heart 86:649-655. doi:10.1136/heart.86.6. 649

46. Garlichs CD, John S, Schmeisser A, Eskafi S, Stumpf C, Karl M, Goppelt-Struebe M, Schmieder R, Daniel WG (2001) Upregulation of CD40 and CD40 ligand (CD154) in patients with moderate hypercholesterolemia. Circulation 104:2395-2400. doi: $10.1161 / \mathrm{hc} 4501.099312$

47. Ginhoux F, Schultze JL, Murray PJ, Ochando J, Biswas SK (2015) New insights into the multidimensional concept of macrophage ontogeny, activation and function. Nat Immunol 17:34-40. doi:10.1038/ni.3324

48. Gray D, Dullforce P, Jainandunsing S (1994) Memory B cell development but not germinal center formation is impaired by in vivo blockade of CD40-CD40 ligand interaction. J Exp Med 180:141-155. doi:10.1084/jem.180.1.141

49. Haapamaki J, Roine RP, Turunen U, Farkkila MA, Arkkila PE (2011) Increased risk for coronary heart disease, asthma, and connective tissue diseases in inflammatory bowel disease. J Crohns Colitis 5:41-47. doi:10.1016/j.crohns.2010.09.008

50. Habib GB, Heibig J, Forman SA, Brown BG, Roberts R, Terrin ML, Bolli R (1991) Influence of coronary collateral vessels on myocardial infarct size in humans. Results of phase I thrombolysis in myocardial infarction (TIMI) trial. The TIMI Investigators. Circulation 83:739-746. doi:10.1161/01.CIR.83. 3.739

51. Hamm A, Veschini L, Takeda Y, Costa S, Delamarre E, Squadrito ML, Henze AT, Wenes M, Serneels J, Pucci F, Roncal C, Anisimov A, Alitalo K, De Palma M, Mazzone M (2013) PHD2 regulates arteriogenic macrophages through TIE2 signalling. EMBO Mol Med 5:843-857. doi:10.1002/emmm.201302695

52. Hansen JF (1989) Coronary collateral circulation: clinical significance and influence on survival in patients with coronary artery occlusion. Am Heart J 117:290-295. doi:10.1016/00028703(89)90771-0

53. Hassan SB, Sorensen JF, Olsen BN, Pedersen AE (2014) AntiCD40-mediated cancer immunotherapy: an update of recent and ongoing clinical trials. Immunopharmacol Immunotoxicol 36:96-104. doi:10.3109/08923973.2014.890626

54. He JQ, Oganesyan G, Saha SK, Zarnegar B, Cheng G (2007) TRAF3 and its biological function. In: Wu $\mathrm{H}$ (ed) TNF receptor associated factors (TRAFs). Springer, New York, pp 48-59

55. Heil M, Eitenmuller I, Schmitz-Rixen T, Schaper W (2006) Arteriogenesis versus angiogenesis: similarities and differences. J Cell Mol Med 10:45-55. doi:10.1111/j.1582-4934.2006. tb00290.x

56. Heil M, Schaper W (2004) Influence of mechanical, cellular, and molecular factors on collateral artery growth (arteriogenesis). Circ Res 95:449-458. doi:10.1161/01.RES.0000141145.78900. 44

57. Hilgendorf I, Swirski FK, Robbins CS (2015) Monocyte fate in atherosclerosis. Arterioscler Thromb Vasc Biol 35:272-279. doi:10.1161/ATVBAHA.114.303565

58. Hollander MR, Horrevoets AJ, van Royen N (2014) Cellular and pharmacological targets to induce coronary arteriogenesis. Curr Cardiol Rev 10:29-37. doi:10.2174/1573403X113099990003

59. Hristov M, Gumbel D, Lutgens E, Zernecke A, Weber C (2010) Soluble CD40 ligand impairs the function of peripheral blood angiogenic outgrowth cells and increases neointimal formation after arterial injury. Circulation 121:315-324. doi:10.1161/CIR CULATIONAHA.109.862771

60. Hussein M, Berenson JR, Niesvizky R, Munshi N, Matous J, Sobecks R, Harrop K, Drachman JG, Whiting N (2010) A phase I multidose study of dacetuzumab (SGN-40; humanized antiCD40 monoclonal antibody) in patients with multiple myeloma. Haematologica 95:845-848. doi:10.3324/haematol.2009.008003

61. Idzkowska E, Eljaszewicz A, Miklasz P, Musial WJ, Tycinska AM, Moniuszko M (2015) The role of different monocyte subsets in the pathogenesis of atherosclerosis and acute coronary syndromes. Scand J Immunol 82:163-173. doi:10.1111/sji. 12314

62. Ilhan F, Kalkanli ST (2015) Atherosclerosis and the role of immune cells. World J Clin Cases 3:345-352. doi:10.12998/ wjcc.v3.i4.345

63. J-i Inoue, Gohda J, Akiyama T (2007) Characteristics and biological functions of TRAF6. In: Wu $\mathrm{H}$ (ed) TNF receptor associated factors (TRAFs). Springer, New York, pp 72-79

64. Inoue J, Ishida T, Tsukamoto N, Kobayashi N, Naito A, Azuma S, Yamamoto $\mathrm{T}$ (2000) Tumor necrosis factor receptor-associated factor (TRAF) family: adapter proteins that mediate cytokine signaling. Exp Cell Res 254:14-24. doi:10.1006/excr.1999.4733

65. Inoue M, Arikawa T, Chen YH, Moriwaki Y, Price M, Brown M, Perfect JR, Shinohara ML (2014) T cells down-regulate macrophage TNF production by IRAK1-mediated IL-10 expression and control innate hyperinflammation. Proc Natl Acad Sci USA 111:5295-5300. doi:10.1073/pnas.1321427111

66. Inoue Y, Otsuka T, Niiro H, Nagano S, Arinobu Y, Ogami E, Akahoshi M, Miyake K, Ninomiya I, Shimizu S, Nakashima H, Harada M (2004) Novel regulatory mechanisms of CD40- 
induced prostanoid synthesis by IL-4 and IL-10 in human monocytes. J Immunol 172:2147-2154. doi:10.4049/jimmunol. 172.4.2147

67. Ishida TK, Tojo T, Aoki T, Kobayashi N, Ohishi T, Watanabe T, Yamamoto T, Inoue J (1996) TRAF5, a novel tumor necrosis factor receptor-associated factor family protein, mediates CD40 signaling. Proc Natl Acad Sci USA 93:9437-9442. doi:10.1073/ pnas.93.18.9437

68. Kahlenberg JM, Kaplan MJ (2013) Mechanisms of premature atherosclerosis in rheumatoid arthritis and lupus. Annu Rev Med 64:249-263. doi:10.1146/annurev-med-060911-090007

69. Kalunian KC, Davis JC Jr, Merrill JT, Totoritis MC, Wofsy D, Group I-LS (2002) Treatment of systemic lupus erythematosus by inhibition of $\mathrm{T}$ cell costimulation with anti-CD154: a randomized, double-blind, placebo-controlled trial. Arthritis Rheum 46:3251-3258. doi:10.1002/art.10681

70. Kasran A, Boon L, Wortel CH, Hogezand RA, Schreiber S, Goldin E, Boer M, Geboes K, Rutgeerts P, Ceuppens JL (2005) Safety and tolerability of antagonist anti-human CD40 Mab ch5D12 in patients with moderate to severe Crohn's disease. Aliment Pharmacol Ther 22:111-122. doi:10.1111/j.1365-2036. 2005.02526.x

71. Kawabe T, Naka T, Yoshida K, Tanaka T, Fujiwara H, Suematsu S, Yoshida N, Kishimoto T, Kikutani H (1994) The immune responses in CD40-deficient mice: impaired immunoglobulin class switching and germinal center formation. Immunity 1:167-178. doi:10.1016/1074-7613(94)90095-7

72. Kayahan H, Sari I, Cullu N, Yuksel F, Demir S, Akarsu M, Goktay Y, Unsal B, Akpinar H (2012) Evaluation of early atherosclerosis in patients with inflammatory bowel disease. Dig Dis Sci 57:2137-2143. doi:10.1007/s10620-012-2148-x

73. Kelly C, Jefferies C, Cryan SA (2011) Targeted liposomal drug delivery to monocytes and macrophages. J Drug Deliv 2011:727241. doi:10.1155/2011/727241

74. Keul P, Lucke S, von Wnuck Lipinski K, Bode C, Graler M, Heusch G, Levkau B (2011) Sphingosine-1-phosphate receptor 3 promotes recruitment of monocyte/macrophages in inflammation and atherosclerosis. Circ Res 108:314-323. doi:10.1161/ CIRCRESAHA.110.235028

75. Kiener PA, Moran-Davis P, Rankin BM, Wahl AF, Aruffo A, Hollenbaugh D (1995) Stimulation of CD40 with purified soluble gp39 induces proinflammatory responses in human monocytes. J Immunol 155:4917-4925

76. Konno H, Yamamoto T, Yamazaki K, Gohda J, Akiyama T, Semba K, Goto H, Kato A, Yujiri T, Imai T, Kawaguchi Y, Su B, Takeuchi O, Akira S, Tsunetsugu-Yokota Y, Inoue J (2009) TRAF6 establishes innate immune responses by activating NFkappaB and IRF7 upon sensing cytosolic viral RNA and DNA. PLoS One 4:e5674. doi:10.1371/journal.pone.0005674

77. Krajewski S, Zapata JM, Krajewska M, VanArsdale T, Shabaik A, Gascoyne RD, Reed JC (1997) Immunohistochemical analysis of in vivo patterns of TRAF-3 expression, a member of the TNF receptor-associated factor family. $J$ Immunol 159:5841-5852

78. Kuwana M, Nomura S, Fujimura K, Nagasawa T, Muto Y, Kurata Y, Tanaka S, Ikeda Y (2004) Effect of a single injection of humanized anti-CD154 monoclonal antibody on the plateletspecific autoimmune response in patients with immune thrombocytopenic purpura. Blood 103:1229-1236. doi:10.1182/blood2003-06-2167

79. Laman JD, Claassen E, Noelle RJ (1996) Functions of CD40 and its ligand, gp39 (CD40L). Crit Rev Immunol 16:59-108. doi:10. 1615/CritRevImmunol.v16.i1.40

80. Lee AH, Happerfield LC, Bobrow LG, Millis RR (1997) Angiogenesis and inflammation in invasive carcinoma of the breast. J Clin Pathol 50:669-673. doi:10.1136/jcp.50.8.669
81. Lee CW, Hwang I, Park CS, Lee H, Park DW, Kang SJ, Lee SW, Kim YH, Park SW, Park SJ (2013) Macrophage heterogeneity of culprit coronary plaques in patients with acute myocardial infarction or stable angina. Am J Clin Pathol 139:317-322. doi:10.1309/AJCP7KEYGN3OBGQX

82. Lee SY, Choi Y (2007) TRAF1 and its biological functions. Adv Exp Med Biol 597:25-31. doi:10.1007/978-0-387-70630-6_2

83. Leroyer AS, Rautou PE, Silvestre JS, Castier Y, Leseche G, Devue C, Duriez M, Brandes RP, Lutgens E, Tedgui A, Boulanger CM (2008) CD40 ligand+ microparticles from human atherosclerotic plaques stimulate endothelial proliferation and angiogenesis a potential mechanism for intraplaque neovascularization. J Am Coll Cardiol 52:1302-1311. doi:10.1016/j.jacc. 2008.07.032

84. Li G, Sanders JM, Bevard MH, Sun Z, Chumley JW, Galkina EV, Ley K, Sarembock IJ (2008) CD40 ligand promotes Mac-1 expression, leukocyte recruitment, and neointima formation after vascular injury. Am J Pathol 172:1141-1152. doi:10.2353/ ajpath.2008.070633

85. Libby P, Pasterkamp G (2015) Requiem for the "vulnerable plaque'. Eur Heart J 36:2984-2987. doi:10.1093/eurheartj/ehv349

86. Lievens D, Zernecke A, Seijkens T, Soehnlein O, Beckers L, Munnix IC, Wijnands E, Goossens P, van Kruchten R, Thevissen L, Boon L, Flavell RA, Noelle RJ, Gerdes N, Biessen EA, Daemen MJ, Heemskerk JW, Weber C, Lutgens E (2010) Platelet CD40L mediates thrombotic and inflammatory processes in atherosclerosis. Blood 116:4317-4327. doi:10.1182/blood-201001-261206

87. Lindau A, Hardtner C, Hergeth SP, Blanz KD, Dufner B, Hoppe N, Anto-Michel N, Kornemann J, Zou J, Gerhardt LM, Heidt T, Willecke F, Geis S, Stachon P, Wolf D, Libby P, Swirski FK, Robbins CS, McPheat W, Hawley S, Braddock M, Gilsbach R, Hein L, von Zur Muhlen C, Bode C, Zirlik A, Hilgendorf I (2016) Atheroprotection through SYK inhibition fails in established disease when local macrophage proliferation dominates lesion progression. Basic Res Cardiol 111:20. doi:10.1007/ s00395-016-0535-8

88. Liu J, Thewke DP, Su YR, Linton MF, Fazio S, Sinensky MS (2005) Reduced macrophage apoptosis is associated with accelerated atherosclerosis in low-density lipoprotein receptornull mice. Arterioscler Thromb Vasc Biol 25:174-179. doi:10. 1161/01.ATV.0000148548.47755.22

89. Ludewig B, Henn V, Schroder JM, Graf D, Kroczek RA (1996) Induction, regulation, and function of soluble TRAP (CD40 ligand) during interaction of primary CD4+ CD45RA $+\mathrm{T}$ cells with dendritic cells. Eur J Immunol 26:3137-3143. doi:10.1002/ eji. 1830261246

90. Lutgens E, Cleutjens KBJM, Heeneman S, Koteliansky VE, Burkly LC, Daemen MJAP (2000) Both early and delayed antiCD40L antibody treatment induces a stable plaque phenotype. Proc Natl Acad Sci USA 97:7464-7469. doi:10.1073/pnas.97. 13.7464

91. Lutgens E, Gorelik L, Daemen MJ, de Muinck ED, Grewal IS, Koteliansky VE, Flavell RA (1999) Requirement for CD154 in the progression of atherosclerosis. Nat Med 5:1313-1316. doi: $10.1038 / 15271$

92. Lutgens E, Lievens D, Beckers L, Wijnands E, Soehnlein O, Zernecke A, Seijkens T, Engel D, Cleutjens J, Keller AM, Naik SH, Boon L, Oufella HA, Mallat Z, Ahonen CL, Noelle RJ, de Winther MP, Daemen MJ, Biessen EA, Weber C (2010) Deficient CD40-TRAF6 signaling in leukocytes prevents atherosclerosis by skewing the immune response toward an antiinflammatory profile. J Exp Med 207:391-404. doi:10.1084/ jem.20091293 
93. Mach F, Schonbeck U, Sukhova GK, Atkinson E, Libby P (1998) Reduction of atherosclerosis in mice by inhibition of CD40 signalling. Nature 394:200-203. doi:10.1038/28204

94. Meier P, Gloekler S, Zbinden R, Beckh S, de Marchi SF, Zbinden S, Wustmann K, Billinger M, Vogel R, Cook S, Wenaweser P, Togni M, Windecker S, Meier B, Seiler C (2007) Beneficial effect of recruitable collaterals: a 10-year follow-up study in patients with stable coronary artery disease undergoing quantitative collateral measurements. Circulation 116:975-983. doi:10.1161/CIRCULATIONAHA.107.703959

95. Melter M, Reinders ME, Sho M, Pal S, Geehan C, Denton MD, Mukhopadhyay D, Briscoe DM (2000) Ligation of CD40 induces the expression of vascular endothelial growth factor by endothelial cells and monocytes and promotes angiogenesis in vivo. Blood 96:3801-3808

96. Merrill JT (2013) Co-stimulatory molecules as targets for treatment of lupus. Clin Immunol 148:369-375. doi:10.1016/j. clim.2013.04.012

97. Missiou A, Kostlin N, Varo N, Rudolf P, Aichele P, Ernst S, Munkel C, Walter C, Stachon P, Sommer B, Pfeifer D, Zirlik K, MacFarlane L, Wolf D, Tsitsikov E, Bode C, Libby P, Zirlik A (2010) Tumor necrosis factor receptor-associated factor 1 (TRAF1) deficiency attenuates atherosclerosis in mice by impairing monocyte recruitment to the vessel wall. Circulation 121:2033-2044. doi:10.1161/CIRCULATIONAHA.109.895037

98. Missiou A, Rudolf P, Stachon P, Wolf D, Varo N, Aichele P, Colberg C, Hoppe N, Ernst S, Munkel C, Walter C, Sommer B, Hilgendorf I, Nakano H, Bode C, Zirlik A (2010) TRAF5 deficiency accelerates atherogenesis in mice by increasing inflammatory cell recruitment and foam cell formation. Circ Res 107:757-766. doi:10.1161/CIRCRESAHA.110.219295

99. Mitchell AJ, Roediger B, Weninger W (2014) Monocyte homeostasis and the plasticity of inflammatory monocytes. Cell Immunol 291:22-31. doi:10.1016/j.cellimm.2014.05.010

100. Miyahara T, Koyama H, Miyata T, Shigematsu H, Inoue J, Takato T, Nagawa H (2006) Inflammatory responses involving tumor necrosis factor receptor-associated factor 6 contribute to in-stent lesion formation in a stent implantation model of rabbit carotid artery. J Vasc Surg 43:592-600. doi:10.1016/j.jvs.2005. 11.010

101. Moore KJ, Tabas I (2011) Macrophages in the pathogenesis of atherosclerosis. Cell 145:341-355. doi:10.1016/j.cell.2011.04. 005

102. Moreno PR, Purushothaman KR, Fuster V, Echeverri D, Truszczynska H, Sharma SK, Badimon JJ, O'Connor WN (2004) Plaque neovascularization is increased in ruptured atherosclerotic lesions of human aorta: implications for plaque vulnerability. Circulation 110:2032-2038. doi:10.1161/01.CIR. 0000143233.87854 .23

103. Morrison MD, Reiley W, Zhang M, Sun SC (2005) An atypical tumor necrosis factor (TNF) receptor-associated factor-binding motif of B cell-activating factor belonging to the TNF family (BAFF) receptor mediates induction of the noncanonical NFkappaB signaling pathway. J Biol Chem 280:10018-10024. doi:10.1074/jbc.M413634200

104. Mosser DM, Edwards JP (2008) Exploring the full spectrum of macrophage activation. Nat Rev Immunol 8:958-969. doi:10. 1038/nri2448

105. Mozaffarian D, Benjamin EJ, Go AS, Arnett DK, Blaha MJ, Cushman M, de Ferranti S, Despres JP, Fullerton HJ, Howard VJ, Huffman MD, Judd SE, Kissela BM, Lackland DT, Lichtman JH, Lisabeth LD, Liu S, Mackey RH, Matchar DB, McGuire DK, Mohler ER 3rd, Moy CS, Muntner P, Mussolino ME, Nasir K, Neumar RW, Nichol G, Palaniappan L, Pandey DK, Reeves MJ, Rodriguez CJ, Sorlie PD, Stein J, Towfighi A, Turan TN, Virani SS, Willey JZ, Woo D, Yeh RW, Turner MB
(2015) Heart disease and stroke statistics - 2015 update: a report from the American Heart Association. Circulation 131:e29-322. doi:10.1161/cir.0000000000000152

106. Mukundan L, Bishop GA, Head KZ, Zhang LH, Wahl LM, Suttles J (2005) TNF receptor-associated factor 6 is an essential mediator of CD40-activated proinflammatory pathways in monocytes and macrophages. J Immunol 174:1081-1090. doi:10.4049/jimmunol.174.2.1081

107. Munroe ME, Bishop GA (2007) A costimulatory function for T cell CD40. J Immunol 178:671-682. doi:10.4049/jimmunol.178. 2.671

108. Narula J, Nakano M, Virmani R, Kolodgie FD, Petersen R, Newcomb R, Malik S, Fuster V, Finn AV (2013) Histopathologic characteristics of atherosclerotic coronary disease and implications of the findings for the invasive and noninvasive detection of vulnerable plaques. $\mathrm{J}$ Am Coll Cardiol 61:1041-1051. doi:10.1016/j.jacc.2012.10.054

109. Ng MKC, Quinn CM, McCrohon JA, Nakhla S, Jessup W, Handelsman DJ, Celermajer DS, Death AK (2003) Androgens up-regulate atherosclerosis-related genes in macrophages from males but not females: molecular insights into gender differences in atherosclerosis. J Am Coll Cardiol 42:1306-1313. doi:10.1016/j.jacc.2003.07.002

110. Noelle RJ, Ledbetter JA, Aruffo A (1992) CD40 and its ligand, an essential ligand-receptor pair for thymus-dependent B-cell activation. Immunol Today 13:431-433. doi:10.1016/01675699(92)90068-I

111. Omrane I, Benammar-Elgaaied A (2015) The immune microenvironment of the colorectal tumor: involvement of immunity genes and microRNAs belonging to the TH17 pathway. Biochim Biophys Acta 1856:28-38. doi:10.1016/j.bbcan. 2015.04.001

112. Pamukcu B, Lip GY, Snezhitskiy V, Shantsila E (2011) The CD40-CD40L system in cardiovascular disease. Ann Med 43:331-340. doi:10.3109/07853890.2010.546362

113. Pancoska P, Carr BI (2014) Macro- and micro-environmental factors in clinical hepatocellular cancer. Semin Oncol 41:185-194. doi:10.1053/j.seminoncol.2014.03.001

114. Peters AL, Stunz LL, Bishop GA (2009) CD40 and autoimmunity: the dark side of a great activator. Semin Immunol 21:293-300. doi:10.1016/j.smim.2009.05.012

115. Pinchuk LM, Polacino PS, Agy MB, Klaus SJ, Clark EA (1994) The role of CD40 and CD80 accessory cell molecules in dendritic cell-dependent HIV-1 infection. Immunity 1:317-325. doi:10.1016/1074-7613(94)90083-3

116. Pluda JM (1997) Tumor-associated angiogenesis: mechanisms, clinical implications, and therapeutic strategies. Semin Oncol 24:203-218

117. Poe JC, Wagner DH Jr, Miller RW, Stout RD, Suttles J (1997) IL-4 and IL-10 modulation of CD40-mediated signaling of monocyte IL-1beta synthesis and rescue from apoptosis. J Immunol 159:846-852

118. Portillo JA, Feliciano LM, Okenka G, Heinzel F, Subauste MC, Subauste CS (2012) CD40 and tumour necrosis factor-alpha cooperate to up-regulate inducuble nitric oxide synthase expression in macrophages. Immunology 135:140-150. doi:10.1111/j. 1365-2567.2011.03519.x

119. Pullen SS, Miller HG, Everdeen DS, Dang TT, Crute JJ, Kehry MR (1998) CD40-tumor necrosis factor receptor-associated factor (TRAF) interactions: regulation of CD40 signaling through multiple TRAF binding sites and TRAF heterooligomerization. Biochemistry 37:11836-11845. doi:10.1021/ bi981067q

120. Recio C, Oguiza A, Mallavia B, Lazaro I, Ortiz-Munoz G, Lopez-Franco O, Egido J, Gomez-Guerrero C (2015) Gene delivery of suppressors of cytokine signaling (SOCS) inhibits 
inflammation and atherosclerosis development in mice. Basic Res Cardiol 110:8. doi:10.1007/s00395-014-0458-1

121. Reinders ME, Sho M, Robertson SW, Geehan CS, Briscoe DM (2003) Proangiogenic function of CD40 ligand-CD40 interactions. J Immunol 171:1534-1541. doi:10.4049/jimmunol.171.3. 1534

122. Remskar M, Li HY, Chyu KY, Shah PK, Cercek B (2001) Absence of CD40 signaling is associated with an increase in intimal thickening after arterial injury. Circ Res 88:390-394. doi:10.1161/01.RES.88.4.390

123. Rogacev KS, Cremers B, Zawada AM, Seiler S, Binder N, Ege P, Grosse-Dunker G, Heisel I, Hornof F, Jeken J, Rebling NM, Ulrich C, Scheller B, Bohm M, Fliser D, Heine GH (2012) $\mathrm{CD} 14++\mathrm{CD} 16+$ monocytes independently predict cardiovascular events: a cohort study of 951 patients referred for elective coronary angiography. J Am Coll Cardiol 60:1512-1520. doi:10.1016/j.jacc.2012.07.019

124. Sallusto F, Lanzavecchi A (1994) Efficient presentation of soluble antigen by cultured human dendritic cells is maintained by granulocyte/macrophage colony-stimulating factor plus interleukin 4 and downregulated by tumor necrosis factor alpha. J Exp Med 179:1109-1118. doi:10.1084/jem.179.4.1109

125. Sanchez-Gaytan BL, Fay F, Lobatto ME, Tang J, Ouimet M, Kim Y, Staay SEMvd, Rijs SMv, Priem B, Zhang L, Fisher EA, Moore KJ, Langer R, Fayad ZA, Mulder WJM (2015) HDLmimetic PLGA nanoparticle to target atherosclerosis plaque macrophages. Bioconjug Chem 26:443-451. doi:10.1021/ bc500517k

126. Schirmer SH, Bot PT, Fledderus JO, van der Laan AM, Volger OL, Laufs U, Bohm M, de Vries CJ, Horrevoets AJ, Piek JJ, Hoefer IE, van Royen N (2010) Blocking interferon beta stimulates vascular smooth muscle cell proliferation and arteriogenesis. J Biol Chem 285:34677-34685. doi:10.1074/jbc.M110. 164350

127. Schonbeck U, Libby P (2001) CD40 signaling and plaque instability. Circ Res 89:1092-1103. doi:10.1161/hh2401.101272

128. Schonbeck U, Sukhova GK, Shimizu K, Mach F, Libby P (2000) Inhibition of CD40 signaling limits evolution of established atherosclerosis in mice. Proc Natl Acad Sci USA 97:7458-7463. doi:10.1073/pnas.97.13.7458

129. Seibold K, Ehrenschwender M (2015) p62 regulates CD40mediated NFkappaB activation in macrophages through interaction with TRAF6. Biochem Biophys Res Commun 464:330-335. doi:10.1016/j.bbrc.2015.06.153

130. Shimada K (2009) Immune system and atherosclerotic disease: heterogeneity of leukocyte subsets participating in the pathogenesis of atherosclerosis. Circ J 73:994-1001. doi:10.1253/ circj.CJ-09-0277

131. Song Z, Jin R, Yu S, Nanda A, Granger DN, Li G (2012) Crucial role of CD40 signaling in vascular wall cells in neointimal formation and vascular remodeling after vascular interventions. Arterioscler Thromb Vasc Biol 32:50-64. doi:10.1161/ATV BAHA.111.238329

132. Song Z, Jin R, Yu S, Rivet JJ, Smyth SS, Nanda A, Granger DN, $\mathrm{Li} \mathrm{G}$ (2011) CD40 is essential in the upregulation of TRAF proteins and NF-kappaB-dependent proinflammatory gene expression after arterial injury. PLoS One 6:e23239. doi:10. 1371/journal.pone.0023239

133. Song Z, Zhu X, Jin R, Wang C, Yan J, Zheng Q, Nanda A, Granger DN, Li G (2014) Roles of the kinase TAK1 in CD40mediated effects on vascular oxidative stress and neointima formation after vascular injury. PLoS One 9:e101671. doi:10. 1371/journal.pone.0101671

134. Stoger JL, Gijbels MJ, van der Velden S, Manca M, van der Loos CM, Biessen EA, Daemen MJ, Lutgens E, de Winther MP (2012) Distribution of macrophage polarization markers in human atherosclerosis. Atherosclerosis 225:461-468. doi:10. 1016/j.atherosclerosis.2012.09.013

135. Suttles J, Stout RD (2009) Macrophage CD40 signaling: a pivotal regulator of disease protection and pathogenesis. Semin Immunol 21:257-264. doi:10.1016/j.smim.2009.05.011

136. Swirski FK, Libby P, Aikawa E, Alcaide P, Luscinskas FW, Weissleder R, Pittet MJ (2007) Ly-6Chi monocytes dominate hypercholesterolemia-associated monocytosis and give rise to macrophages in atheromata. J Clin Invest 117:195-205. doi:10. 1172/JCI29950

137. Szabolcs MJ, Cannon PJ, Thienel U, Chen R, Michler RE, Chess L, Yellin MJ (2000) Analysis of CD154 and CD40 expression in native coronary atherosclerosis and transplant associated coronary artery disease. Virchows Arch 437:149-159. doi:10.1007/ s004280000215

138. Takeda Y, Costa S, Delamarre E, Roncal C, Leite de Oliveira R, Squadrito ML, Finisguerra V, Deschoemaeker S, Bruyere F, Wenes M, Hamm A, Serneels J, Magat J, Bhattacharyya T, Anisimov A, Jordan BF, Alitalo K, Maxwell P, Gallez B, Zhuang ZW, Saito Y, Simons M, De Palma M, Mazzone M (2011) Macrophage skewing by Phd2 haplodeficiency prevents ischaemia by inducing arteriogenesis. Nature 479:122-126. doi:10.1038/nature 10507

139. Thapa SD (2015) IBD and extent of coronary atherosclerosis. Inflamm Bowel Dis 21:E1. doi:10.1097/MIB.0000000000000276

140. Troidl C, Jung G, Troidl K, Hoffmann J, Mollmann H, Nef H, Schaper W, Hamm CW, Schmitz-Rixen T (2013) The temporal and spatial distribution of macrophage subpopulations during arteriogenesis. Curr Vasc Pharmacol 11:5-12. doi:10.2174/ 15701611130103

141. Vaina S, Milkas A, Crysohoou C, Stefanadis C (2015) Coronary artery disease in women: from the yentl syndrome to contemporary treatment. World J Cardiol 7:10-18. doi:10.4330/wjc.v7. i1.10

142. Vaitaitis GM, Wagner DH Jr (2013) CD40 interacts directly with RAG1 and RAG2 in autoaggressive T cells and Fas prevents CD40-induced RAG expression. Cell Mol Immunol 10:483-489. doi:10.1038/cmi.2013.24

143. Vaitaitis GM, Wagner DH Jr (2008) High distribution of CD40 and TRAF2 in Th40 T cell rafts leads to preferential survival of this auto-aggressive population in autoimmunity. PLoS One 3:e2076. doi:10.1371/journal.pone.0002076

144. van den Berg SM, Seijkens TT, Kusters PJ, Zarzycka B, Beckers L, den Toom M, Gijbels MJ, Chatzigeorgiou A, Weber C, de Winther MP, Chavakis T, Nicolaes GA, Lutgens E (2015) Blocking CD40-TRAF6 interactions by small-molecule inhibitor 6860766 ameliorates the complications of diet-induced obesity in mice. Int J Obes (Lond) 39:782-790. doi:10.1038/ijo. 2014.198

145. van der Laan AM, Schirmer SH, de Vries MR, Koning JJ, Volger OL, Fledderus JO, Bastiaansen AJ, Hollander MR, Baggen JM, Koch KT, Baan J Jr, Henriques JP, van der Schaaf RJ, Vis MM, Mebius RE, van der Pouw Kraan TC, Quax PH, Piek JJ, Horrevoets AJ, van Royen N (2012) Galectin-2 expression is dependent on the rs7291467 polymorphism and acts as an inhibitor of arteriogenesis. Eur Heart J 33:1076-1084. doi:10.1093/eurheartj/ehr220

146. van Vlijmen BJ, Gerritsen G, Franken AL, Boesten LS, Kockx MM, Gijbels MJ, Vierboom MP, van Eck M, Van De Water B, van Berkel TJ, Havekes LM (2001) Macrophage p53 deficiency leads to enhanced atherosclerosis in APOE*3-Leiden transgenic mice. Circ Res 88:780-786. doi:10.1161/hh0801.089261

147. Vidalain PO, Azocar O, Servet-Delprat C, Rabourdin-Combe C, Gerlier D, Manie S (2000) CD40 signaling in human dendritic cells is initiated within membrane rafts. EMBO J 19:3304-3313. doi:10.1093/emboj/19.13.3304 
148. Vogel DY, Glim JE, Stavenuiter AW, Breur M, Heijnen P, Amor S, Dijkstra CD, Beelen RH (2014) Human macrophage polarization in vitro: maturation and activation methods compared. Immunobiology 219:695-703. doi:10.1016/j.imbio.2014.05.002

149. Vogel DY, Vereyken EJ, Glim JE, Heijnen PD, Moeton M, van der Valk P, Amor S, Teunissen CE, van Horssen J, Dijkstra CD (2013) Macrophages in inflammatory multiple sclerosis lesions have an intermediate activation status. J Neuroinflamm 10:35. doi:10.1186/1742-2094-10-35

150. Wagner AH, Gebauer M, Guldenzoph B, Hecker M (2002) 3-Hydroxy-3-methylglutaryl coenzyme A reductase-independent inhibition of CD40 expression by atorvastatin in human endothelial cells. Arterioscler Thromb Vasc Biol 22:1784-1789. doi:10.1161/01.ATV.0000037098.20829.31

151. Walsh MC, Lee J, Choi Y (2015) Tumor necrosis factor receptor- associated factor 6 (TRAF6) regulation of development, function, and homeostasis of the immune system. Immunol Rev 266:72-92. doi:10.1111/imr.12302

152. Willecke F, Tiwari S, Rupprecht B, Wolf D, Hergeth S, Hoppe N, Dufner B, Schulte L, Anto Michel N, Bukosza N, Marchini T, Jackel M, Stachon P, Hilgendorf I, Zeschky K, Schleicher R, Langer HF, von Zur Muhlen C, Bode C, Peter K, Zirlik A (2014) Interruption of classic CD40L-CD40 signalling but not of the novel CD40L-Mac-1 interaction limits arterial neointima formation in mice. Thromb Haemost 112:379-389. doi:10.1160/ TH13-08-0653

153. Wong KL, Yeap WH, Tai JJ, Ong SM, Dang TM, Wong SC (2012) The three human monocyte subsets: implications for health and disease. Immunol Res 53:41-57. doi:10.1007/ s12026-012-8297-3

154. Woollard KJ, Geissmann F (2010) Monocytes in atherosclerosis: subsets and functions. Nat Rev Cardiol 7:77-86. doi:10.1038/ nrcardio. 2009.228

155. Xu LG, Li LY, Shu HB (2004) TRAF7 potentiates MEKK3induced AP1 and CHOP activation and induces apoptosis. J Biol Chem 279:17278-17282. doi:10.1074/jbc.C400063200

156. Yamane J, Ishibashi S, Sakaguchi M, Kuroiwa T, Kanemura Y, Nakamura M, Miyoshi H, Sawamoto K, Toyama Y, Mizusawa H, Okano H (2011) Transplantation of human neural stem/progenitor cells overexpressing galectin-1 improves functional recovery from focal brain ischemia in the Mongolian gerbil. Mol Brain 4:35. doi:10.1186/1756-6606-4-35
157. Yan J, Wang C, Du R, Liu P, Chen G (2010) Association analysis of $\mathrm{CD} 40$ gene polymorphism with acute coronary syndrome. Clin Exp Med 10:253-258. doi:10.1007/s10238-0100092-7

158. Yildirim C, Vogel DY, Hollander MR, Baggen JM, Fontijn RD, Nieuwenhuis S, Haverkamp A, de Vries MR, Quax PH, GarciaVallejo JJ, van der Laan AM, Dijkstra CD, van der Pouw Kraan TC, van Royen N, Horrevoets AJ (2015) Galectin-2 induces a proinflammatory, anti-arteriogenic phenotype in monocytes and macrophages. PLoS One 10:e0124347. doi:10.1371/journal. pone. 0124347

159. Yona S, Jung S (2010) Monocytes: subsets, origins, fates and functions. Curr Opin Hematol 17:53-59. doi:10.1097/MOH. 0b013e3283324f80

160. Yuan M, Fu H, Ren L, Wang H, Guo W (2015) Soluble CD40 ligand promotes macrophage foam cell formation in the etiology of atherosclerosis. Cardiology 131:1-12. doi:10.1159/ 000374105

161. Zapata JM (2003) TNF-receptor-associated factors as targets for drug development. Expert Opin Ther Targets 7:411-425. doi:10. 1517/14728222.7.3.411

162. Zapata JM, Reed JC (2002) TRAF1: lord without a RING. Sci STKE 2002:pe27. doi:10.1126/stke.2002.133.pe27

163. Zarzycka B, Seijkens T, Nabuurs SB, Ritschel T, Grommes J, Soehnlein O, Schrijver R, van Tiel CM, Hackeng TM, Weber C, Giehler F, Kieser A, Lutgens E, Vriend G, Nicolaes GA (2015) Discovery of small molecule CD40-TRAF6 inhibitors. J Chem Inf Model 55:294-307. doi:10.1021/ci500631e

164. Zeller I, Srivastava S (2014) Macrophage functions in atherosclerosis. Circ Res 115:e83-e85. doi:10.1161/CIRCRE SAHA.114.305641

165. Zhang JM, Wang Y, Miao YJ, Zhang Y, Wu YN, Jia LX, Qi YF, Du J (2013) Knockout of CD8 delays reendothelialization and accelerates neointima formation in injured arteries of mouse via TNF-alpha inhibiting the endothelial cells migration. PLoS One 8:e62001. doi:10.1371/journal.pone.0062001

166. Ziegler-Heitbrock L (2007) The CD14+ CD16+ blood monocytes: their role in infection and inflammation. J Leukoc Biol 81:584-592. doi:10.1189/jlb.0806510 